Mitsubishi, Chugai, Teijin Pharma, Torii, Nippon Shinyaku, Pfizer. UCB. Nippon Kayaku, YL biologics, Bayer and Bristol-Meyers., Consultant for: MSD, Ayumi, AbbVie, Eisai, Ono, Astellas, Daiichi-Sankyo, Taisyo-Toyama, Takeda, TanabeMitsubishi, Chugai, Teijin Pharma, Torii, Nippon Shinyaku, Pfizer. UCB. Nippon Kayaku, YL biologics, Bayer and Bristol-Meyers., Speakers bureau: MSD, Ayumi, AbbVie, Eisai, Ono, Astellas, Daiichi-Sankyo, Taisyo-Toyama, Takeda, TanabeMitsubishi, Chugai, Teijin Pharma, Torii, Nippon Shinyaku, Pfizer. UCB. Nippon Kayaku, YL biologics, Bayer and Bristol-Meyers.

DOI: 10.1136/annrheumdis-2018-eular.1046

\section{SAT0146 AT DIAGNOSIS OF RHEUMATOID ARTHRITIS, AT-RISK PATIENTS FOLLOWED IN CCP+ CLINIC SHOWED MILDER DISEASE ACTIVITY THAN CONVENTIONALLY REFERRED PATIENTS.}

L. Duquenne ${ }^{1,2,{ }^{*}}$, P. Pentony ${ }^{1,2}$, K. Mankia ${ }^{1,2}$, J. Nam ${ }^{1,2}$, L. Hunt ${ }^{1,2}$, A. L. $\operatorname{Tan}^{1,2}$, L. Garcia-Montoya ${ }^{1,2}$, P. Emery ${ }^{1,2} .{ }^{1}$ Leeds Institute of Rheumatic and Musculoskeletal Medicine, University of Leeds, ${ }^{2}$ NIHR Leeds Biomedical Research Centre, Chapel Allerton Hospital, Leeds, United Kingdom

Background: Early treatment of rheumatoid arthritis (RA) improves clinical and radiological outcomes ${ }^{1}$. Risk stratification models can identify patients at high risk of developing $\mathrm{RA}^{2-5}$ which may lead to an extension of the window of opportunity. Whether identifying and following at-risk individuals improves outcomes after the development of RA however is yet to be determined.

Objectives: The hypothesis is that patients followed in a specific at-risk clinic will have less severe disease at diagnosis than those referred via the conventional route if/when they develop $R A$.

Methods: In two single-centre prospective observational cohorts, patients fulfilling the 2010 EULAR classification criteria for RA were compared on a demographic and clinical approach. The first group was composed of 59 patients positive for anti-cyclic citrullinated protein antibodies (CCP) with non-specific musculoskeletal symptoms, considered to be "at-risk of RA", who were followed until RA diagnosis. The second group was composed of 92 CCP positive RA patients referred to a standard 'Early Arthritis' rheumatology clinic.

Results: Demographic data at RA development were consistent between both groups including smoking history and BMI. Immunological features were also similar. CCP titre: at risk median 193U/ml (IQR 41,300), standard care 300U/ml (IQR $81,300, \mathrm{p}=0.176)$ ). Rheumatoid factor (RF) titre: at risk median $84 \mathrm{iU} / \mathrm{mL}(\mathrm{IQR}$ $15,223)$, standard care $87 \mathrm{iU} / \mathrm{mL}$ (IQR18,161, $\mathrm{p}=0.850$ ). RF positivity: at risk $75 \%$, standard care $70 \%(p=0.544)$. High-titre CCP blood levels: at risk $95 \%$, standard care $97 \%(p=0.566)$.

As shown in table 1, DAS28CRP score were significantly lower in the at risk group than in standard care, this was due to a difference in the general health Visual Analogue Scale score and the CRP levels. Patients in the at risk group also had fewer swollen large joints and reported significantly shorter time between onset of subjective joint swelling and diagnosis. There was no difference between the presence of erosions on ultrasound scans (at risk: $39 \%$, standard care $38 \%$, $\mathrm{p}=0.921)$.

\begin{tabular}{llll}
\hline & $\begin{array}{l}\text { At Risk of } \\
\text { RA }^{*}\end{array}$ & $\begin{array}{l}\text { Standard } \\
\text { care }^{*}\end{array}$ & $\begin{array}{l}\text { P- } \\
\text { value }\end{array}$ \\
\hline Age mean (SD) & 55.3 y $(12.6)$ & 56.4 y $(19.1)$ & 0.711 \\
Women & $73 \%$ & $71 \%$ & 0.815 \\
BMI mean (SD) & $28(5.4)$ & $27(6.5)$ & 0.299 \\
Ever smoker & $70 \%$ & $55 \%$ & 0.075 \\
DAS28CRP & $3.9(3.2,4.6)$ & $4.9(3.4,5.6)$ & 0.003 \\
TJC28 & $5(3,9)$ & $7(2,14)$ & 0.447 \\
SJC28 & $2(1,5)$ & $4(2,9)$ & 0.001 \\
GH VAS & $41(18,64)$ & $57(37,75)$ & 0.003 \\
CRP & $5.4(0,11)$ & $26(18,49)$ & 0.000 \\
HAQ & $10(2,17)$ & $12(5,20)$ & 0.197 \\
Large joint swelling mean (SD) & $0.14(0.4)$ & $0.39(0.7)$ & 0.014 \\
Weeks before subjective Swelling to RA & $6(2,12)$ & $29(16,52)$ & 0.00
\end{tabular}

diagnosis

${ }^{*}$ Median (IQR) unless specified

Conclusions: Patients who were diagnosed with RA while being followed in an at-risk cohort had milder disease activity and less pain than those diagnosed through standard referral despite equivalent demographics and serology. This reflects an earlier diagnosis and hence shorter exposure to inflammation. Followup will be required to see if these differences convert to long-term benefits.

\section{REFERENCES:}

[1] van der Heide. Ann Intern Med 1996;124(8).

[2] Rakieh. Ann Rheum Dis 2015;74(9).

[3] Van de Stadt. Ann Rheum Dis 2013;72(12).

[4] Van Steenbergen. Ann Rheum Dis 2016;75(10).

[5] Nam JL. Ann Rheum Dis 2016;75(12).
Disclosure of Interest: None declared

DOI: 10.1136/annrheumdis-2018-eular.5704

\section{SAT0147 PRESENCE OF HEPATITIS B VIRUS IN SYNOVIUM AND ITS CLINICAL SIGNIFICANCE IN RHEUMATOID ARTHRITIS}

L.-J. Yang ${ }^{1}$, Y.-L. Chen ${ }^{1}$, J. Jing ${ }^{1}$, Y.-Q. Mo ${ }^{1}$, J.-D. Ma ${ }^{1}$, L.-F. Chen ${ }^{1}$, J.-Z. Lin ${ }^{1}$, Z. H. Yang ${ }^{2}$, T. Yan ${ }^{3}$, D.-H. Zheng', F. Pessler ${ }^{4,5}$, L. Dai ${ }^{1} .{ }^{1}$ Department of Rheumatology, ${ }^{2}$ Department of Radiology, Sun Yat-sen Memorial Hospital, Sun Yat-sen University, ${ }^{3}$ Zhongshan School of Medicine, Sun Yat-sen University, Guangzhou, China, ${ }^{4}$ TWINCORE Center for Experimental and Clinical Infection Research, Hannover, ${ }^{5} \mathrm{Helmholtz}$ Center for Infection Research, Braunschweig, Germany

Background: Previous studies have shown that hepatitis B virus (HBV) infection may be associated with rheumatoid arthritis (RA). However, no study regarding the presence of HBV in the synovial membrane from RA patients has been reported.

Objectives: To investigate the presence of HBV in RA synovium and determine its influence on histopathological characteristics of synovitis as well as clinical and radiographic outcomes in $R A$.

Methods: 57 consecutive patients with active RA (DAS28-CRP $\geq 2.6$ ) and qualified synovium (at least 6 pieces of synovial tissues per patient, containing lining layer and sublining area) obtained by closed Parker-Pearson needle biopsy who had completed one year follow-up were retrospectively recruited from a prospec tive RA cohort $(n=239)$. The patients were divided into chronic HBV infection ( $\mathrm{CHB}$, positive HBsAg and/or HBV DNA in serum persisting for over 6 months; $\mathrm{n}=11$ ), resolved HBV (negative HBsAg and HBV DNA in serum, but positive anti$\mathrm{HBc} ; \mathrm{n}=22$ ), and non-HBV (negative $\mathrm{HBsAg}, \mathrm{HBeAg}$, anti-HBe, anti-HBc, and HBV DNA in serum, regardless of anti-HBs; $n=24$ ) groups according to baseline HBV infection status. Clinical data were collected at baseline and follow-up visits at months $1,3,6$, and 12. Radiographic assessments of hand/wrist at baseline and month 12 were performed with the Sharp/van der Heijde-modified sharp score (mTSS). Serial tissue sections were stained immunohistochemically for $\mathrm{HBsAg}$, HBcAg, CD3, CD15, CD20, CD34, CD38, and CD68. Nested PCR was used to detect HBV $S$ gene DNA in synovium.

Results: Immunohistochemical staining and nested PCR revealed the presence of $\mathrm{HBcAg}$ and $\mathrm{S}$ gene DNA in the synovium from RA patients with $\mathrm{CHB}$ (figure 1). Compared with the non-CHB group $(n=46)$, significantly more CD15-positive neutrophils, CD20-positive B cells, and CD68-positive macrophages infiltrated the $\mathrm{CHB}$ synovium (all $\mathrm{p}<0.05$ ), together with smaller improvements from baseline in most disease activity indicators mainly at month 12 . A significantly higher percentage of $\mathrm{CHB}$ patients experienced one-year radiographic progression ( $\Delta$ mTSS $>0.5$ units/year, $64 \%$ vs. $26 \%, p=0.024)$. Multivariate logistic regression analysis showed that $\mathrm{CHB}$ status (OR: $14.230,95 \% \mathrm{Cl}: 2.213-95.388 ; \mathrm{p}=0.006$ ) and the total count of CD68-positive macrophages (OR: $1.002,95 \% \mathrm{Cl}: 1.001-$ $1.003 ; p=0.003)$ were independently associated with one-year radiographic progression.

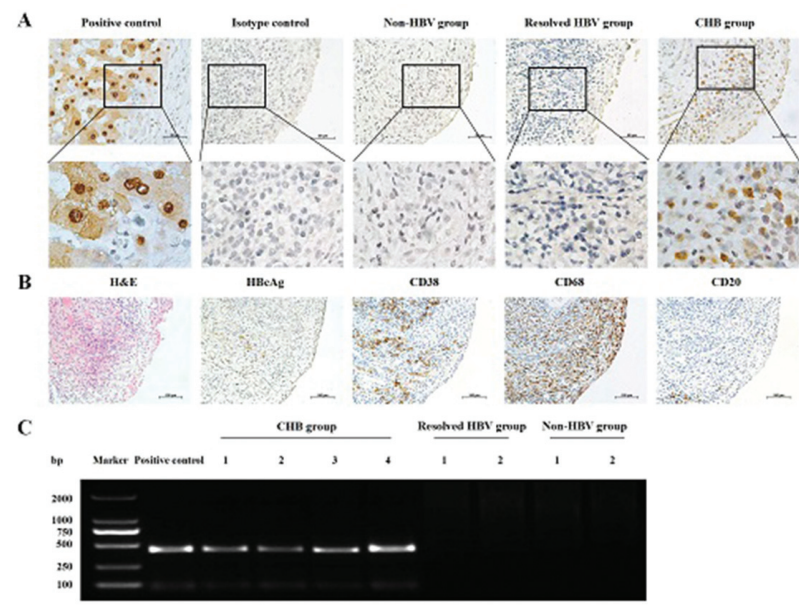

Figure 1 Identification of HBV in RA synovium. (A) Representative immunohistochemical staining for $\mathrm{HBcAg}$ in RA synovium. Representative images illustrated detection of $\mathrm{HBcAg}$ in a RA patient with $\mathrm{CHB}$, but not in RA patients with resolved $\mathrm{HBV}$ or no infection. (B) Representative staining of HBCAg in one RA patient with CHB compared to stains for CD38 and CD68. Serial sections of synovium from one RA patient with $\mathrm{CHB}$ were stained with $\mathrm{H} \& \mathrm{E}$ and immunohistochemically. $\mathrm{HBcAg}$ immunoreactivity was 